\title{
Thermo-alkaliphilic halotolerant detergent compatible protease(s) of Bacillus tequilensis MTCC 9585
}

\author{
Imran Khan, Puja Gupta and Jyoti Vakhlu* \\ School of Biotechnology, University of Jammu, Jammu-180006, India. \\ Accepted, 19 September, 2011
}

\begin{abstract}
An extra-cellular thermo-alkaliphillic protease producing Bacillus was isolated from the soil and identified to be Bacillus tequilensis MTCC 9585 by microscopic, colony morphology, biochemical and $16 S$ ribotyping. B. tequilensis MTCC 9585 produces protease up to $21 \mathrm{~h}$ of growth but interestingly $90 \%$ of the protease production occurred, just after $6 \mathrm{~h}$ of growth. The organism grew as well as and produced enzyme at wide $\mathrm{pH}(5$ to 12$)$ and temperature range $\left(4,25,37\right.$ and $\left.50^{\circ} \mathrm{C}\right)$, though optimum temperature and $\mathrm{pH}$ for the growth of the Bacillus were $37^{\circ} \mathrm{C}$ and $\mathrm{pH} 7.0$. Optimum $\mathrm{pH}$ for enzyme activity coincided with optimum $\mathrm{pH}$ for enzyme production at $\mathrm{pH} 10$. Optimum temperature for enzyme activity was $60^{\circ} \mathrm{C}$ and the enzyme stayed stable over the period of 270 days ( 9 months) at $10^{\circ} \mathrm{C}$. Metal ions like $\mathrm{Ca}^{2+}, \mathrm{Mg}^{2+}, \mathrm{K}^{+}$increased the enzyme activity whereas $\mathrm{Cu}^{2+}, \mathrm{Zn}^{2+}$ inhibit the activity slightly. Wash performance and stain removal efficiency increased when partially purified enzyme was used in conjunction with selected detergent. $B$. tequilensis can be a potential candidate for use in detergent industry because: of couple of reasons such as (i) $90 \%$ of the protease is produced only after $6 \mathrm{~h}$ of growth (economically viable), (ii) it's activity in wide $\mathrm{pH}$ and temperature range (iii) it's stability over the period of 9 months at $10^{\circ} \mathrm{C}$ indicating good shelf life and (iv) detergent compatibility.
\end{abstract}

Key words: Bacillus tequilensis, alkaline protease, $\mathrm{pH}$, temperature, detergent compatibility.

\section{INTRODUCTION}

Commercial proteases are produced by various bacteria and about $35 \%$ of the total microbial enzymes used in detergent are from bacterial sources (Huang et al., 2006). Bacillus in particular has been studied for the production of proteases in general and in special reference to detergent proteases. Various species of Bacillus produce a variety of extracellular and intracellular protease (Beison et al., 2000; Huang et al., 2003; Nascimento et al., 2006; Rao et al., 2007). Conventionally, detergents are used at elevated washing temperatures, but currently there is considerable interest in the identification of alkaline proteases, which are effective over a wide temperature and $\mathrm{pH}$ range. Bacillus is otherwise an attractive microbial producer for variety of reasons, including their high growth rates leading to short fermentation cycles, production of extracellular proteins and are regarded as GRAS (Generally regarded as safe) industrial tool. Subtilisin (Carlsberg) produced by Bacillus

\footnotetext{
*Corresponding author. E-mail: jyotivakhlu@gmail.com.
}

licheniformis and Subtilisin Novo produced by Bacillus amyloliquefaciens have been the enzymes of choice in detergent so far (Horikoshi, 1990). Complexity of the patent rules and development of new detergent formulations have led to renewed interest in search of novel enzymes from nature. Here we report isolation of thermostable, alkaliophilic protease produced by Bacillus tequilensis MTCC-9585 and its stability as well as the activity in the presence of commercial powered detergents.

\section{MATERIALS AND METHODS}

Bacterial strain and the media used

The Bacillus was isolated from the agriculture soil of R.S. Pura Jammu, $\mathrm{J}$ and $\mathrm{K}$, India and deposited in culture repository at IMTech Chandigarh (India). Luria Bertani medium was used for routine growth and maintenance of the bacterium at $37^{\circ} \mathrm{C}$ in $\mathrm{BOD}$ incubator. Protease assay media was used to monitor the protease production qualitatively (Usharani et al., 2010). The diluted samples were plated on the production media plates and incubated in BOD at $37^{\circ} \mathrm{C}$ for 12 to $16 \mathrm{~h}$ for the formation of zone of clearance 
showing hydrolysis of skim milk.

\section{Protease estimation assay}

The protease activity was measured by method given by Sarath et al. (1989).

\section{Bacterial identification}

Identification of the bacteria was done by colony morphology, microscopic and biochemical analysis (Sneath, 1986). The results were confirmed by $16 \mathrm{~S}$ ribotyping analysis done at culture identification centre at IMtech Chandigarh.

\section{Protease production profile vis- a- vis growth}

An overnight grown colony was inoculated in $300 \mathrm{ml}$ broth and kept in incubator shaker at $37^{\circ} \mathrm{C}$ with constant shaking of $220 \mathrm{rpm}$. After every $3 \mathrm{~h}, 1 \mathrm{ml}$ sample was collected under sterile conditions and stored on ice. The growth was measured by measuring optical density of sample (diluted 10 fold in LB broth) at $600 \mathrm{~nm}$ and protease produced was measured by protease estimation method. The generation time was calculated by the method given by Cappuccino and Sherman (2007).

\section{Effect of $\mathrm{pH}$ and temperature on growth and production of enzyme}

Effect of $\mathrm{pH}$ on the protease production and bacterial growth was determined by growing the bacterial isolate on protease assay media in the $\mathrm{pH}$ range of 5 to 12 prepared in appropriate buffer e.g. $50 \mathrm{mM}$ Sodium acetate ( $\mathrm{pH}$ range 4.5 to 5.5 ), $50 \mathrm{mM}$ Potassium ( $\mathrm{pH}$ range 6 to 7.5), $50 \mathrm{mM}$ Tris $\mathrm{Cl}$ ( $\mathrm{pH}$ range 7.5 to 9), $50 \mathrm{mM}$ $\mathrm{NaOH}-G l y c i n e$ buffer ( $\mathrm{pH}$ range 9.5 to 10) and $50 \mathrm{mM} \mathrm{Na}_{2} \mathrm{HPO}_{4}$ $\mathrm{NaOH} \mathrm{pH}$ range (10 to 12 ) for $21 \mathrm{~h}$ at $37^{\circ} \mathrm{C}$ in incubator shaker at $220 \mathrm{rpm}$. To study the effect of temperature on the production of enzyme and growth bacterial isolate was grown in protease production media at various temperatures $4,25,37$ and $50^{\circ} \mathrm{C}$ for 21 $\mathrm{h}$ at $\mathrm{pH} 7$ in incubator shaker with $220 \mathrm{rpm}$. The growth and protease production by the Bacillus was measured by the methods already described.

\section{Effect of $\mathrm{pH}$ on the enzyme stability and activity}

The effect of $\mathrm{pH}$ on the stability of isolated protease was determined incubating the $100 \mu \mathrm{g}$ of $60 \%$ ammonium sulphate precipitate fraction of crude extract in $500 \mu \mathrm{l}$ of buffers with different $\mathrm{pH}$ (from 5 to 12) for $30 \mathrm{~min}$ at $37^{\circ} \mathrm{C}$. The stability profile of the enzyme under various $\mathrm{pH}$ was determined by estimating the residual protease activity (Sarath et al., 1989). The optimal $\mathrm{pH}$ for the enzyme activity was determined by carrying out enzyme assay at various $\mathrm{pH}$ in the range of 5 to 12 by using buffers mentioned above at $60^{\circ} \mathrm{C}$ (temperature optima).

\section{Effect of temperature on the enzyme stability and activity}

Effect of temperature on protease activity was determined by incubating the reaction mixture containing substrate and enzyme for 30 min in Tris- $\mathrm{HCl}$ buffer $(\mathrm{pH} \mathrm{10)}$ at different temperatures ranging from 4 to $80^{\circ} \mathrm{C}$ and the optimal temperature for enzyme activity was measured by performing the enzyme assay at various temperatures in Tris- $\mathrm{HCl}$ buffer ( $\mathrm{pH}$ 10). Enzyme activity was measured quantitatively by hydrolysis of azo-casein (Sarath et al., 1989).

\section{Effect of metal ions on the enzyme activity}

The effect of metal ion the protease activity was determined by incubating $10 \mathrm{mM}$ solution of different salts $\left(\mathrm{CuSO}_{4}, \mathrm{ZnSO}_{4}, \mathrm{CaSO}_{4}\right.$, $\mathrm{MgCl} 2, \mathrm{KCl})$ at $60^{\circ} \mathrm{C}$ for $30 \mathrm{~min}$ with reaction mixture containing substrate and enzyme in Tris- $\mathrm{HCl}$ buffer $(\mathrm{pH} \mathrm{10)}$ and the activity was measured subsequently.

Compatibility with detergents and enhancement of their destaining properties

Three detergent brands namely Surf excel, Ariel, Tide were used for studying compatibility of alkaline protease under buffered and normal conditions. Detergent solutions were prepared as per directions given on their respective sache. Casein solution $(0.2 \%$ $\mathrm{w} / \mathrm{v}$ ) was used as substrate, prepared either in buffer (carbonatebicarbonate buffer, $0.1 \mathrm{M}, \mathrm{pH} 9.5$ ) that is for buffered conditions or in distilled water that is for normal conditions of assay. Both buffered and non-buffered solutions were used in reaction mixture comprising of $2 \mathrm{ml}$ of casein solution, $5 \mathrm{mg} / \mathrm{ml}$ of detergent solution and $0.040 \mathrm{mg} / \mathrm{ml}$ of alkaline protease. The reaction mixture was incubated at optimized conditions for $60 \mathrm{~min}$ followed by protease assay. Controls were taken which comprised of assay mixture without detergent under similar conditions. The de-staining property was studied by dipping pieces of cloth artificially stained with blood either in detergent solution or detergent solution supplemented with enzyme followed by incubation for $10 \mathrm{~min}$ at $60^{\circ} \mathrm{C}$.

\section{RESULTS AND DISCUSSION}

Commercial detergents available anywhere in the world are mixture of detergent and stain digesters, to which hydrolases in general and proteases in particular contribute a lot. Mesophilic bacterium, B. tequilensis MTCC 9585 producing thermophillic alkaliphillic proteases was isolated from the agricultutral soil of R.S. Pura Jammu, J and $\mathrm{K}$, India.

\section{Screening, characterization and growth properties}

The Bacillus is a fast growing bacterium, as it reaches its stationary phase with in $24 \mathrm{~h}$ with log phase extending from 6 to $21 \mathrm{~h}$. The generation time calculated using method given by Cappuccino and Sherman (2007) is $3 \mathrm{~h}$. The Bacillus was identified morphological, microscopically and on the basis of $16 S$ ribotyping as $B$. tequilensis and was given accession number 9585 by IMtech, Chandigarh, India (Table 1).

B. tequilensis MTCC 9585 was characterised as best protease producer out of 150 microbes screened on basis of the size of the clearing halo formed on agar diffusion assay plate containing milk casesin $(0.5 \%)$ as substrate. Bacillus species is a common producers of proteases that is proteases are isolated from Bacillus pumilus (Huang et al., 2003), Bacillus firmus 7728 (Rao et al., 2007), Bacillus sp (Oberoi et al., 2001), 
Table 1. Comparative account of Bacillus proteases.

\begin{tabular}{|c|c|c|c|c|c|c|c|c|}
\hline No & Name & $\begin{array}{l}\text { Growth } \\
\text { in } h\end{array}$ & $\begin{array}{c}\text { Enzyme } \\
\text { Production (h) }\end{array}$ & $\begin{array}{c}\text { Optimum } \\
\text { Temperature }\left({ }^{\circ} \mathrm{C}\right) \\
\end{array}$ & $\begin{array}{c}\text { Optimum } \\
\text { pH }\end{array}$ & $\begin{array}{l}\text { Temperature } \\
\text { stability }\left({ }^{\circ} \mathrm{C}\right)\end{array}$ & pH stability & References \\
\hline 1 & B. pumilus & 36 & $16-28$ & 55 & 10 & $30-60$ & $6-11$ & Huang et al., 2003 \\
\hline 2 & B. licheniformis LBBL-1 & 48 & 48 & 60 & 8 & 60 & $5-11$ & Olajuyigbe and Ajele., 2008 \\
\hline 3 & B. circulans & 96 & 96 & 60 & 9 & $40-65$ & $8-11$ & Jaswal et al 2007 \\
\hline 4 & B. firmus 7728 & 72 & 48 & 40 & 9 & $20-55$ & $4-12$ & Rao and Narasu., 2007 \\
\hline 5 & B. clausi GMBAE42 & 72 & 72 & 60 & 11.3 & $30-40$ & $9-12.2$ & Kazan et al, 2005 \\
\hline 6 & B. sp.po2 & 24 & 24 & 37 & 8 & 37 & $7-9$ & Patel et al., 2006 \\
\hline 7 & B. subtilus $\mathrm{PE}-11$ & 48 & - & 60 & 10 & 60 & $8-10$ & Kunaminini et al., 2003 \\
\hline 8 & B. halodurans & 48 & 48 & 70 & 10 & $65-75$ & $8-11$ & Ibrahahim et al., 2007 \\
\hline 9 & B. tequelensis MTCC 9585 & 21 & 6 & 60 & 10 & $16-80$ & $7-11$ & This study \\
\hline 10 & Bacillus strain HSO8 & 16 & 16 & 65 & 7.5 & $40-65$ & $7-9$ & Huang et al., 2006 \\
\hline 11 & Bacillus sps & 16 & - & 45 & 10.7 & - & - & Khorsan et al., 2008 \\
\hline 12 & B. stearothermophilus AP4 & 36 & - & 55 & 9 & - & - & Dhandapani et al., 1993 \\
\hline 13 & B. $s p B-21$ & - & - & $55-60$ & - & - & - & Rahman et al., 1994 \\
\hline 14 & B. sp RGR-14 & - & 36 & $45-70$ & 11 & $20-80$ & - & Oberoi et al., 2001 \\
\hline 15 & B. cereus MCMB-326 & - & - & 55 & 9 & $25-65$ & $6-12$ & Nilegaonkar et al., 2007 \\
\hline
\end{tabular}

B. Licheniformis AP-1 (Tang et al., 2004), Bacillus clausii (Kazan et al., 2005), Bacillus Circulans (Jaswal et al., 2007), B. licheniformi (Olajuyigbe et al., 2005) and have been already characterized and the list of Bacillus producing the protease and the variety of proteases produced by them is quite vast. Emphasis is laid on the high temperature or $\mathrm{pH}$ proteases producing Bacillus as this is primary requirement of washing procedure but now because of energy concerns detergent enzymes should also remain active in wide temperature and $\mathrm{pH}$ range for cold as well as hot washes. Protease produced by Bacillus are mainly found to be active in the temperature range of 40 to $60^{\circ} \mathrm{C}$ though Bacillus Sp. RGR-14 produce protease that is stable in temperature range of 20 to $80^{\circ} \mathrm{C}$ and that of $B$. cereus MCMB -326 is stable in the temperature range of 25 to $65^{\circ} \mathrm{C}$ (Nilegaonkar et al., 2007; Oberoi et al., 2011). Thermophillic alkali-stable proteases from $B$. tequilensis in present study have advantage of showing $40 \%$ activity at $16{ }^{\circ} \mathrm{C}$ and $45 \%$ at $80^{\circ} \mathrm{C}$ (Figure 5 ). In the present study protease production time which is after $6 \mathrm{~h}$ of incubation is best in comparison to the proteases production profile of Bacilli known so far. The proteases production starts with the beginning of log phase, just after $6 \mathrm{~h}$ of incubation and extends into stationary phase with $10 \%$ increase at $21 \mathrm{~h}$ of growth (Figure 1). There could be couple of explanations' for this. Enzyme production starts at the beginning of the log phase but gets degraded or inactivated simultaneously by other biomolecules being produced by the Bacillus or else the enzyme production is inhibited by feed back but is stable for the rest of the growth period. So far we have not come across any report in literature where in $90 \%$ of any enzyme is produced at beginning of the log phase by any Bacillus species. Most of the species of Bacillus produce protease after $48 \mathrm{~h}$ of growth (comparison is drawn in Table 2). Though there are reports wherein thermophilic Bacillus strain HSO8 and Bacillus sp. show growth and enzyme production after $16 \mathrm{~h}$ of growth (Huang et al., 2006, Darani et al., 2008). Cellular localization of the protease suggested it to be an extracellular enzyme and this result is in conformation of other Bacillus proteases (Kunamneni et al., 2003, Huang et al., 2006, Darani et al., 2008).

\section{Effect of $\mathrm{pH}$ and temperature on growth and enzyme production}

B. tequilensis MTCC 9585 grows in the $\mathrm{pH}$ range of 5 to 12 but is a mesophile. It shows maximum growth at $\mathrm{pH} 7$ where as optimum $\mathrm{pH}$ for enzyme 


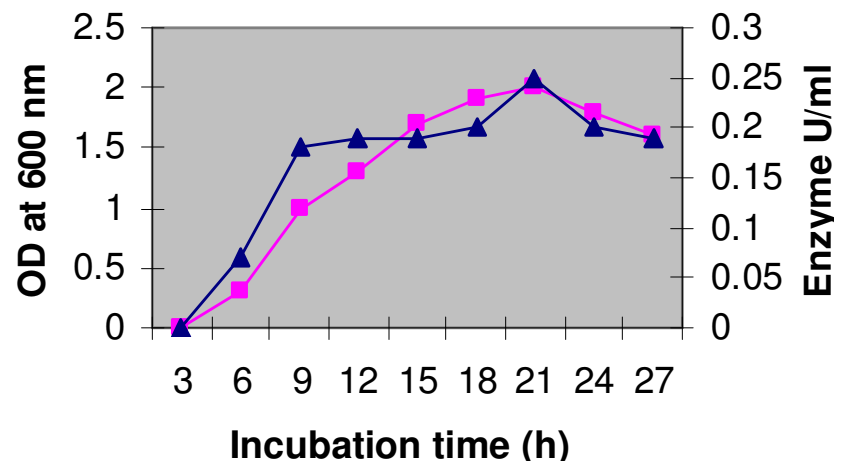

Figure 1. Growth Kinetics along with crude protease production of Bacillus tequilensis Samples were withdrawn at $3 \mathrm{~h}$ intervals for the determination of cell growth $\left(A_{600}\right)(-)$ and protease production $(\mathbf{\Delta})$.

production is 10 . The reason for getting enhanced production could be attributed to the fact that the enzyme is alkaliphillic. The increase in the activity could be due to optimal activity of the enzyme at $10 \mathrm{pH}$ or else optimal enzyme is production at this $\mathrm{pH}$. This Bacillus strain retains $50 \%$ production and $40 \%$ growth at $\mathrm{pH} 11$ and $40 \%$ production and $33 \%$ growth at $\mathrm{pH} 12$ (Figure 2). There are reports ofprotease production at $\mathrm{pH} 10.7$ by Bacillus sp (Darani et al., 2008) at pH 10.5 by B. clausii (Kazan et al., 2005) and at $\mathrm{pH} 10$ by B. pumilus (Huang et al., 2003).

Four temperatures $4,25,37$ and $50^{\circ} \mathrm{C}$ were selected to study their effect on growth and enzyme production by this Bacillus. B. tenquilensis is a mesophile vis a vis temperature also as it shows maximum growth at $37^{\circ} \mathrm{C}$ with about $50 \%$ of growth occurs at $50^{\circ} \mathrm{C}$. Enzyme production is maximum of $37^{\circ} \mathrm{C}$ though about 30,50 and $40 \%$ enzyme production is at 16,50 and $60^{\circ} \mathrm{C}$, respectively. This result is in conformity to most known bacillus proteases (Figure 3 ).

\section{Effect of $\mathrm{pH}$ and Temperature on the activity of proteases}

The maximum protease activity of partially purified was recorded at $\mathrm{pH} 10$ but $87 \%$ of the activity was retained at $\mathrm{pH} 11$ and $\mathrm{pH} 12$. Interestingly the protease is stable in the $\mathrm{pH}$ range of 7 to 10 . Huang and his group (2003) have reported extracellular protease from Bacillus which also shows highest activity at $\mathrm{pH} 10$. There are several other reports of alkaliophillic protease production from Bacillus sp, Thermus aquaticus; Xanthomonas maltophila; Vibrio metscnikovii and bacillus Sp. (Durham et al., 1987; Debette, 1991; Kwon et al., 1994; Matsuzawa et al., 1998; Darani et al., 2008). However this enzyme is interesting as it shows more than $80 \%$ activity at alkaline $\mathrm{pH}$ of 11,12 and is most stable at $\mathrm{pH}$ 10 and is also active at this pH (Figure 4).

The enzyme in the crude extract shows activity in wide temperature range retaining $40 \%$ of the activity retained at two extreme temperatures of 16 and $80^{\circ} \mathrm{C}$ with maximum activity shown at $60^{\circ} \mathrm{C}$. The stability profile indicates that the enzyme is most stable at $37^{\circ} \mathrm{C}$ (Figure 5). There are many comparative reports of thermophillic and thermostable bacilli such as $B$. subtilis PE-11 (Kunamneni et al., 2003) which has temperature optima at $60^{\circ} \mathrm{C}, B$. stearothermophilus AP-4 and Bacillus sp. B21-2 protease with temperature optima of 55 and $60^{\circ} \mathrm{C}$ (Rahman et al., 1994) and bacillus strain HS08 where optimal activity was found at $65^{\circ} \mathrm{C}$ (Huang et al., 2006). Comprehensive comparison is drawn in Table 1, where it's adavantage over commonly used proteases produced by $B$. licheniformis and Bacillus stearothermophilus is quite evident as it is alkaliophilic and shows activity in temperature range of 16 to $80^{\circ} \mathrm{C}$.

\section{Effect of metal ions}

Protease from $B$. tequilensis is a metallo- protease as metal ions affect its function. The activity of the enzyme is inhibited by $\mathrm{Cu}^{2+}$ and $\mathrm{Zn}^{+}$ion but its activity is promoted by $\mathrm{K}^{+}, \mathrm{Ca}^{2+}$ and $\mathrm{Mg}^{2+}$ (Figure 6). The activity of alkaline serine protease from $B$. pumilus is enhanced by $\mathrm{Ca}^{2+}$, $\mathrm{Mg}^{2+}$ and $\mathrm{Na}^{+}$where as $\mathrm{Cu}^{2+}$ and $\mathrm{Zn}^{2+}$ inhibit the activity slightly (Huang et al., 2003). In contrast to our results $\mathrm{Zn}^{2+}$ does not inhibit activity of the protease produced by $B$. stearothermophilus (Dhandapan et al., 1994). The cations have been reported to increase the thermal stability of the Bacillus proteases. Nevertheless there are reports where neither metal ions nor EDTA showed any significant effect on the enzyme activity (Kunamneni et al., 2003).

\section{Wash test performance and shelf life of protease}

The visual examination of pieces of cloth (cotton) with various detergent and detergent along with crude enzyme 
Table 2. Morphological, physiological and biochemical characteristics B.tequelensis MTCC 9585.

\begin{tabular}{|c|c|}
\hline Character & Results \\
\hline \multicolumn{2}{|l|}{ Colony morphology } \\
\hline Configuration & Round \\
\hline Margin & Entire \\
\hline Elevation & Raised \\
\hline Surface & Smooth \\
\hline Pigment & Cream \\
\hline Opacity & Opaque \\
\hline \multicolumn{2}{|l|}{ Microscopic analysis } \\
\hline Gram's Reaction & + \\
\hline Cell Shape & Rods \\
\hline Size $(\mu \mathrm{m})$ & $1-4 \mu \mathrm{m}$ \\
\hline Spores & + \\
\hline Position & Central \\
\hline Shape & Oval \\
\hline Sporangia bulging & Non bulged \\
\hline Motility & + \\
\hline \multicolumn{2}{|l|}{ Growth parameters } \\
\hline Aerobic conditions & + \\
\hline Anaerobic conditions & Less growth \\
\hline Optimum temperature & $37^{\circ} \mathrm{C}$ \\
\hline Optimum $\mathrm{pH}$ & 7 \\
\hline \multicolumn{2}{|l|}{ Biochemical analysis } \\
\hline Growth on MacConkey & Nil \\
\hline Indole test & - \\
\hline Methyl red test & - \\
\hline Voges Proskauer Test & + \\
\hline Citrate utilization Test & + \\
\hline $\mathrm{H} 2 \mathrm{~S}$ production & - \\
\hline Gas production & - \\
\hline Casein hydrolysis & - \\
\hline Starch hydrolysis & - \\
\hline Urea hydrolysis & + \\
\hline Nitrate reduction & + \\
\hline Arginine dihydrolase & - \\
\hline Catalase test & + \\
\hline Oxidase Test & + \\
\hline Tween 40, 80 hydrolysis & + \\
\hline \multicolumn{2}{|l|}{ Acid production from } \\
\hline Dextrose & + \\
\hline Maltose & + \\
\hline Xylose & + \\
\hline Mannitol & + \\
\hline
\end{tabular}

shows washing and stain removal efficiency of the detergent increases by adding the enzyme (Figure 7). Many workers have tested efficiency and compatibility of the specific protease production with detergents available in the market, in presence of stabilizers like $\mathrm{CaCl}_{2}$ and glycerin (Kunamneni et al., 2003). The specialty of our 


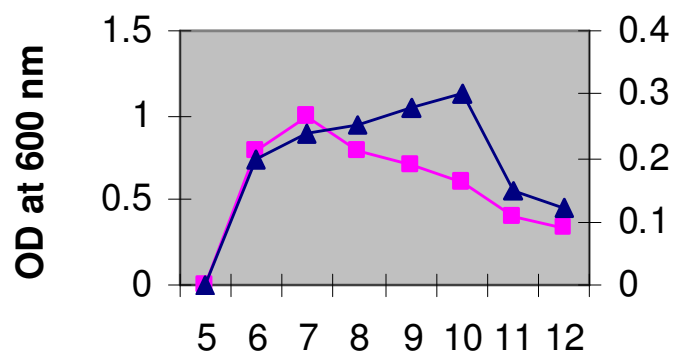

$\mathrm{pH}$

Figure 2. Effect of $\mathrm{pH}$ on growth and protease production of Bacillus tequilensis Samples were taken after $21 \mathrm{~h}$ at $37^{\circ} \mathrm{C}$ under shaking conditions (100 rpm), for the determination of cell growth $\left(A_{600)}(\boldsymbol{m})\right.$ and protease production $(\mathbf{A})$

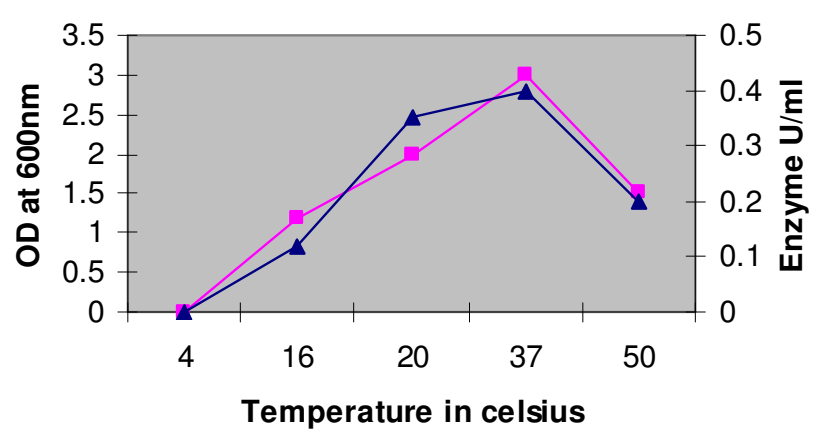

Figure 3. Effect of temperature on growth and protease production of Bacillus tequilensis. Samples were taken after $21 \mathrm{~h}$ under shaking conditions (100 rpm), for the determination of cell growth $\left(A_{600)}(\mathbf{m})\right.$ and protease production $(\mathbf{\Delta})$

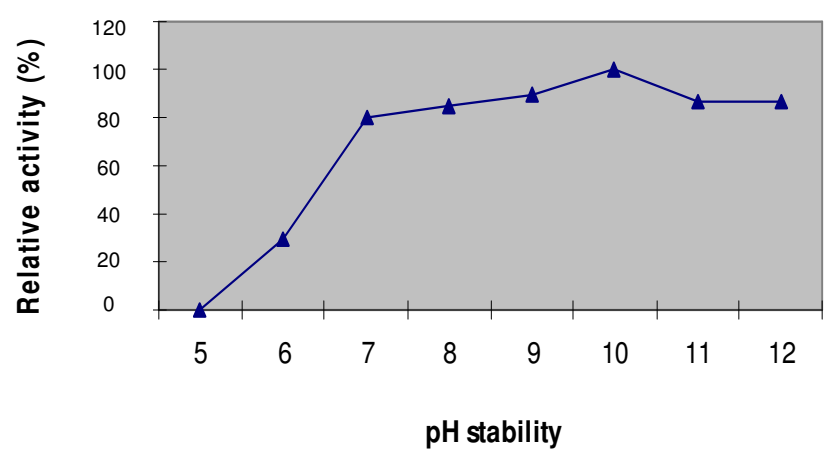

Figure 4. $\mathrm{pH}$ stability profile of protease/s in cell free extract of $B$. tequilensis

enzyme is that it retains its activity in hot as well as cold water depending upon the requirement and in addition its shelf life is longer in comparison to known proteases. The three detergents were already containing the enzyme as

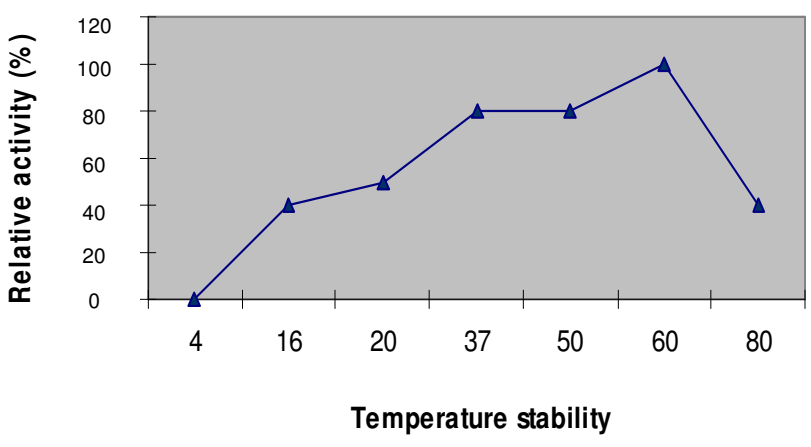

Figure 5. Temperature stability profile of protease/s in cell free extract of $B$. tequilensis.

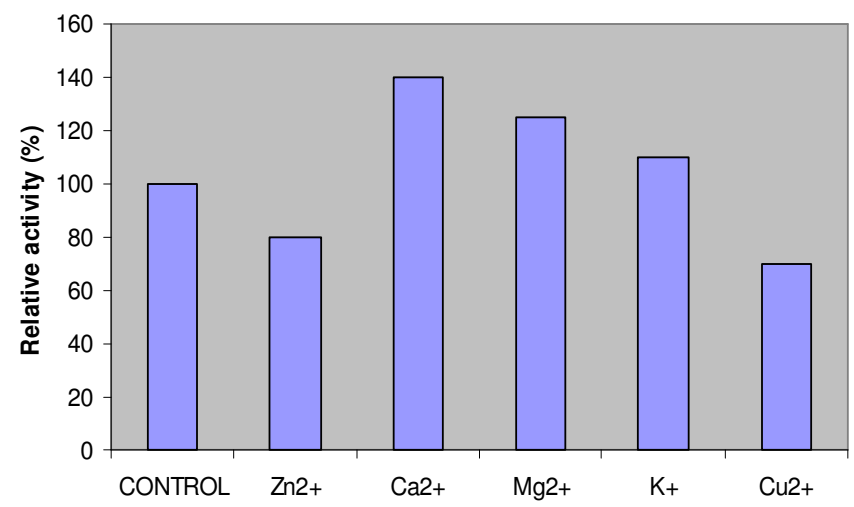

Figure 6. Effect of metal ions on the activity protease/s in cell free extract of $B$. tequilensis.

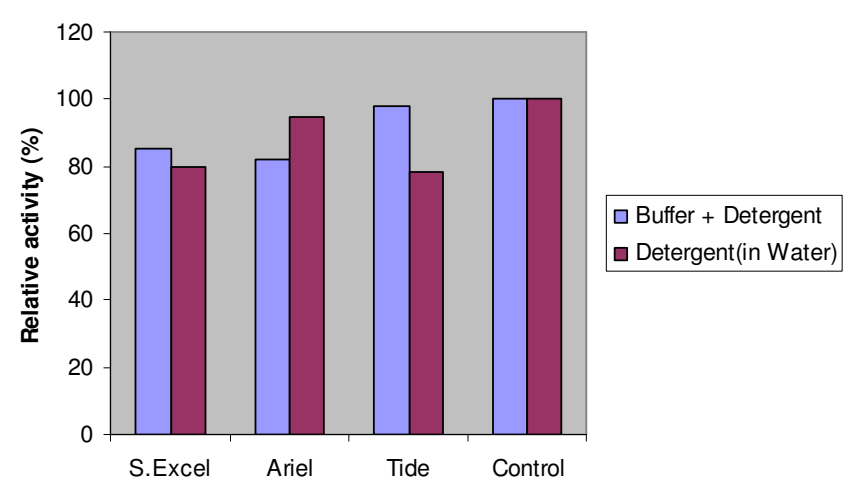

Figure 7. Compatibility of crude protease/s of Bacillus tequilensis with commercial detergents. Enzyme is incubated with detergent (either in buffer or water).

quoted by their manufacturers. Therefore, their suitable controls were also run and their activities were found to be very low compared to those obtained by supplementation with crude proteases of $B$. tequilensis. The crude enzyme preparation when stored at $10^{\circ} \mathrm{C}$ was found to stable over the period of 9 months (Figure 8). 


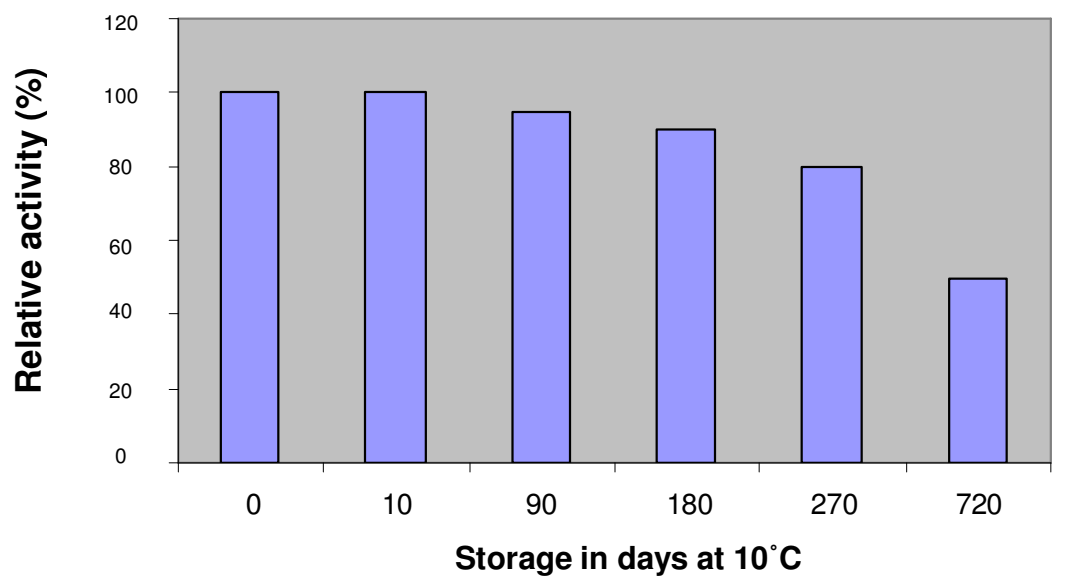

Figure 8. Effect of storage time (in days) at $10^{\circ} \mathrm{C}$ on the protease/s activity of Bacillus tequilensis.

This revealed that the enzyme may be suitable supplement to detergents.

\section{Conclusion}

The production of $90 \%$ enzyme just after $6 \mathrm{~h}$ of growth, the fast growth rate of Bacillus, production of protease that is alkaliphilic and thermophilic but protease showing activity in vast temperature range with compatible destaining properties gives this enzyme an edge over commonly used proteases in the detergent formulations.

\section{ACKNOWLEDGEMENTS}

This study was supported by Department of Science and Technology, Delhi.

\section{REFERENCES}

Beison F, Tiss A, Riviere C, Verger R (2000). Methods of lipase detection and assay: a critical review. European J. Lipid Sci. Technol., 102: 133-153.

Cappuccino JG, Sherman N (2007). Microbiology: A Laboratory Manual, Ed. 8.

Darani KK, Falahatpishe HR, Jalali M (2008). Alkaline protease production on date waste by an alkalophilic Bacillus sp. 2-5 isolated from soil. Afr. J. Biotechnol., 7(10): 1536-1542.

Debette J (1991). Isolation and characterization of an extracellular proteinase produced by a soil strain of Xanthomonas maltophila. Curr. Microbiol., 22: 85-90.

Dhandapani R, Vijayaragavan R (1994). Production of thermophilic extracellular alkaline protease by Bacillus stearothermophilus. Ap-4. World J. Microbiol. Biotechnol., 1: 33-35.

Durham DR, Stewart DB, Stelwag EG (1987). Utility of subtilisin GX as a detergent additive. J. Bacteriol., 169: 2762-2768.

Horikoshi K (1990). Enzymes of alkalophiles In: Microbial Enzymes and Biotechnology (second edition). St. Louis, MO: Elsevier Appl. Sci., 275-294.

Huang GR, Ying TJ, Huo P, Jiang JX (2006). Purification and characterization of a protease from Thermophilic bacillus strain HS08. Afr. J. Biotechnol., 5: 2433-2438.

Huang Q, Peng Y, Wang LH, Zhang Y (2003). Purification and characterization of an extracellular alkaline serine protease with dehairing function from B. pumilus. Curr. Microbiol., 46: 169-73.

Ibrahahim ASS, Nefisa MA, Shayeb EI, Mabrouk SS (2007). Isolation and Identification of Alkaline Protease Producing Alkaliphilic Bacteria from an Egyptian Soda Lake J. Appl. Sci. Res., 3: 1363-1368.

Jaswal RK, Kocher GS (2007). Partial characterization of a crude alkaline protease from Bacillus circulans and its detergent compatibility. Int. J. Microbiol., 4(1): 1-5.

Kazan D, Denizci AA, Oner MNK., Erarslan A (2005). Purification and characteriztion of serine alkaline protease from Bacillus clausii GMBAE 42. J. Ind. Microb. Biotech., 32(8): 335-344.

Kunamneni A, Elliaiah P, Prasad DS (2003). Purification and partial characterization of thermostable serine alkaline protease from a newly isolated Bacillus subtilis PE-11AAPS Pharm. Sci. Tech., 4(4) article 56.

Kwon YT, Kim JO, Moon SY, Lee HH, Rho HM (1994). Extracellular alkaline protease from alkalophilic Vibrio metschnikovii strain RH530. Biotechnol. Lett., 16: 413-418.

Matsuzawa H, Tokugawa K, Hamaok M, Mizoguchi M, Taguchi $\mathrm{H}$, Terada, Kwon S, Ohta T (1998). Purification and characterization of aqualysin I, a thermophilic alkaline serine protease produced by Thermus aquaticus YT-1Eur. J. Biochem., 171: 441-447.

Nascimento WC, Martins ML (2006). Studies on the stability of protease from Bacillus sp. and its compatibility with commercial detergent. Braz. J. Microbiol., 37: 307-311.

Nilegaonkar SS, Zambare VP, Kanekar PP, Dhakephalkar PK, Sarnaik SS (2007). Production and partial characterization of dehairing protease from Bacillus cereus MCM B-326. Bioresour. Technol., 98(6): 1238-1245.

Oberoi R, Beg QK, Puri S, Saxana RK, Gupta R (2001). Characterization and wash performance analysis of an SDS-resistant alkaline protease from a Bacillus sp. World J. Microbiol. Biotechnol., 97: 493-497.

Olajuyigbe FM, Ajele JO (2005). Production dynamics of extracellular protease from Bacillus species. Afr. J. Biotechnol., 4: 776-779

Patel RK, Dodia MS, Joshi RH, Singh SP (2006). Halo-alkaline Protease from a Newly Isolated Haloalkaliphilic Bacillus sp. Isolated from Seawater in Western India. World J. Microbiol. Biotechnol., 22(4): 375-382.

Rahman R, Razak C, Ampon K, Basri M, Yunus W, Salleh A (1994). Purification and characterization of a heat stable protease from Bacillus stearothermophilus F-1. Appl. Microbiol. Biotechnol., 40(6): 822-827.

Rao K, Lakshmi NM (2007). Alkaline Protease from Bacillus firmus 7728 
Afr. J. Biotechnol., 6: 2493-2496.

Sarath G, Motte RS, Wagner FW (1989). Protease assay methods. In R.J Beynon and J.S Bond (eds), Proteolytic enzymes: (A practical approach), IRL PRESS, Oxford, New York: Tokyo.

Sneath PH (1986). Bergey's manual of systematic bacteriology (2). Baltimore: Williams and Wilkins.

Tang XM, Lakay FM, Shen W, Shao WL, Fang HY, Prior BA, Wang ZX, Zhuge (2004). Purification and characterisation of an alkaline protease used in tannery industry from Bacillus licheniformis $\mathrm{J}$. Biotechnol. Lett., 26: 1421-1424.
Usharani B, Muthuraj M (2010). Production and characterization of protease enzyme from Bacillus laterosporus Afr. J. microbiol. Res., 4(11): 1057-1063. 